\title{
$J W A$, a novel signaling molecule, involved in all-trans retinoic acid induced differentiation of HL-60 cells
}

\author{
Shu Huang ${ }^{1}$, Qun Shen ${ }^{1,2}$, Wen-Ge Mao ${ }^{1}$, Ai-Ping Li ${ }^{1}$, Jian Ye ${ }^{1}$, Qi-Zhan Liu ${ }^{1}$, \\ Chang-Ping Zou ${ }^{3}$ \& Jian-Wei Zhou ${ }^{1, *}$ \\ ${ }^{1}$ Department of Molecular Cell Biology and Toxicology, Jiangsu Provincial Key Laboratory of Human \\ Functional Genomics and Applied Toxicology, School of Public Health, Nanjing Medical University, 140 \\ Hanzhong Road, Nanjing, 210029, China; ${ }^{2}$ Department of Hematology, The Traditional Chinese Medicine \\ Hospital of Jiangsu Province, Nanjing, 210029, China, ${ }^{3}$ Department of OB/Gyn and Department of Urology, \\ The University of Arizona, Tucson, AZ, 85724, USA
}

Received 6 July 2005; accepted 28 December 2005

(C) 2006 National Science Council, Taipei

Key words: JWA, ATRA, HL-60 cells, differentiation, RNA interference

\begin{abstract}
Summary
$J W A$ (AF070523) was originally identified as a novel all-trans retinoic acid (ATRA) responsible gene in primary human tracheal bronchial epithelial cells. For the notable performance achieved by ATRA in the differentiation induction therapy, we investigated the role of $J W A$ in ATRA-mediated differentiation of the human myeloid leukemia HL-60 cells. We found that concomitant with the progressive cell differentiation, JWA expression was up-regulated by ATRA in a dose- and time-dependent manner. Inhibition of $J W A$ expression by RNA interference partially blocked ATRA-induced differentiation and growth inhibition of HL-60 cells. Pre-treatment of phorbol-12-myristate-13-acetate (TPA), a PKC activator, decreased ATRAmediated differentiation, companied with the down-regulation of JWA expression. Arsenic trioxide $\left(\mathrm{As}_{2} \mathrm{O}_{3}\right.$, $0.5 \mu \mathrm{M}$ ) enhanced the cellular differentiation induced by $0.01 \mu \mathrm{M}$ ATRA, but had no noticeable effect on the differentiation induced by $0.1 \mu \mathrm{M}$ ATRA. Concurrent with the enhancement, JWA expression was upregulated. All the data suggest that up-regulation of JWA expression is essential for ATRA-induced differentiation of HL-60 cells. And $J W A$, associated with PKC, is involved in its signal pathways. Ideal therapeutic efficacy with low toxicity may be obtained if low doses of ATRA $(0.01 \mu \mathrm{M})$ and $\mathrm{As}_{2} \mathrm{O}_{3}(0.5 \mu \mathrm{M})$ are combined. These findings may present a novel mechanism that cellular differentiation and growth inhibition induced by ATRA are mediated at least in part through regulation of $J W A$ expression. $J W A$ may be a novel molecular marker for ATRA-induced HL-60 cell differentiation. ATRA up-regulates $J W A$ expression by stimulating the transcriptional activity of $J W A$ gene promoter.
\end{abstract}

\section{Introduction}

All-trans retinoic acid (ATRA) is a member of retinoid family including substances structurally or funtionally related to retinol (vitamin A), which exerts profound effects on the survival, growth and

*To whom correspondence should be addressed. Tel: +86-258686-2746; Fax: +86-25-8652-7613; E-mail: jwzhou@njmu. edu.cn differentiation of many cell types during prenatal and adult life [1]. Since 1987, first introduced as the targeted therapy against acute promyelocytic leukemia (APL), ATRA has dramatically changed the clinical outcome of APL from one that was highly lethal to one that now appears highly curable [2]. ATRA has the function because of its capability of inducing the differentiation of leukemia cells into mature granulocytes [2]. From then on, differentiation induction therapy initiated a 
new field of the treatments of malignancies, which traditionally relied on both chemotherapy and radiotherapy [2]. Some of molecular mechanisms of ATRA have been identified in induction of leukemia cells undergoing differentiation by activating target genes via RAR and RXR [3-5]. However, the rest of pharmaceutical roles of ATRA are still unclear. Using ATRA induced cell differentiation model, we originally identified a novel gene, $J W A$ (AF070523) from the primary human tracheal bronchial epithelial cells [6].

During the recent years, several studies have been performed on $J W A$ homologue genes. Lin et al. reported that glutamate transporter-associated protein 3-18 (GTRAP3-18) regulates glutamate uptake by interacting with the 10-transmembranespanning excitatory amino acid carrier 1 (EAAC1) [7-9]. JM4, a novel CC chemokine receptor 5 (CCR5) interacting protein, is suggested to function in trafficking and membrane localization of the receptor [10]. ARL-6 (AF133912) is a member of the Ras superfamily [11]. Another JWA homologue gene (AB09705I) encodes a putative mitogen-activated protein kinase (MAPK) activating protein [12]. It has been proven that Ras superfamily played important roles in cellular proliferation and differentiation [13, 14]. And MAPK signal transduction pathways are among the most widespread mechanisms of eukaryotic cell regulation and coordinate activation of gene transcription, protein synthesis, cell cycle machinery, cell differentiation and death [15]. Together with the notable performance achieved by ATRA in the differentiation induction therapy, we planed series studies and examined $J W A$ potentially associated with leukemia cell directional differentiation [16-19].

Neoplastic myeloid cells are derived from cells, which diverse from the nature differentiating pathway at distinct developmental stages, most often as myeloblasts or promyelocytes. The common feature of these neoplastic cells is their capacity to return to the differentiation pathway by exposure to certain chemical agents, like ATRA [20]. The human myeloid leukemia HL-60 cells are an attractive model for studies of human cell differentiation and have been used repeatedly [20]. In the present study, among the well-examined parameters correlated to differentiation of HL-60 cells, we investigated the correlation between $J W A$ and the cellular differentiation induced by ATRA.
In addition, although ATRA has become the front-line choice of APL therapeutics because of the great achievements of ATRA-induced cell differentiation, ATRA is associated with unique toxicities that can cause retinoic acid syndrome. Even after complete remission, the disease may relapse with resistance to further ATRA treatment [2]. Differentiation-inducing drugs are often used in combination with other compounds that either induce cellular differentiation or exert cytostatic or cytotoxic effects [21, 22]. They may then act in an additive or even synergistic manner [23]. In such combination therapy, drugs are used simultaneously or sequentially, even at lower concentrations that are not effective or only slightly effective when administered alone, to obtain a significant therapeutic gain, e.g., inhibition of tumor cell proliferation and induction of differentiation. Practically, this means that side effects may be reduced considerably without losing the desired maximal therapeutic effect of the drugs [24]. For this purpose, we extended this study by testing the hypothesis that ATRA may cooperate with other well-known inducers of differentiation in HL-60 cells.

Retinoids exert some of their effects on cellular differentiation and reversion of the malignant phenotype through protein kinase $\mathrm{C}$ (PKC) associated signal pathways $[25,26]$. PKC regulates fundamental cellular functions including proliferation, differentiation, tumorigenesis, and apoptosis [27]. It has been demonstrated that the process of differentiation induced by ATRA is accompanied by remarkable changes in terms of subcellular localization and activation state of several PKC isoforms [1, 28]. Bertolaso et al. have proved that PKC plays a major role in granulocytic differentiation of HL-60 cell induced by ATRA [29]. Phorbol-12-myristate-13-acetate (TPA) provokes differentiation of myeloid leukemia cells, like HL-60, NB4 and K562, to monocyte/macrophage-like cells. It is well known that many of the pharmacological and physiological effects of TPA are mediated via PKC [30]. Then may TPA exert a positive cooperativity with ATRA on the induced cellular differentiation? And is $J W A$, correlated with PKC, involved in the signal pathways? Moreover, recent studies have shown that treatment with arsenic trioxide $\left(\mathrm{As}_{2} \mathrm{O}_{3}\right)$ can induce a durable remission in APL patients even in some relapsed cases $[31,32]$ and ATRA and $\mathrm{As}_{2} \mathrm{O}_{3}$ 
can induce non-cross-resistant complete clinical remission in patients with APL [2]. So is there a synergistic effect of $\mathrm{As}_{2} \mathrm{O}_{3}$ on ATRA therapy? In this study, we made a further investigation on the combined effect of ATRA with TPA or $\mathrm{As}_{2} \mathrm{O}_{3}$ and the role of $J W A$ in it.

\section{Materials and methods}

\section{Reagents}

ATRA and TPA were purchased from Sigma (St. Louis, MO). These chemicals were dissolved in ethanol at a concentration of $10 \mathrm{mM}$ (stock solution) and stored at $-20{ }^{\circ} \mathrm{C} . \mathrm{As}_{2} \mathrm{O}_{3}$ (arseniuos acid inj.) water solution was purchased from Harbin Yida Pharmaceutical Co., Ltd. (China) and was stored at $4{ }^{\circ} \mathrm{C}$. All chemicals were diluted with RPMI 1640 to required concentrations shortly before the experiments.

\section{Cell cultures}

Human myeloid leukemia HL-60 cells were purchased from the Institute of Cell Research, Shanghai Life Science Academy (Shanghai, China) and were cultured in RPMI 1640 supplemented with 10\% fetal bovine serum (containing $100 \mathrm{unit} / \mathrm{ml}$ of penicillin and streptomycin respectively) at $37^{\circ} \mathrm{C}$ in a humidified atmosphere of $5 \%$ of $\mathrm{CO}_{2}$ in air. The cells in the exponential growing stage were used for the experiments.

\section{$R N A$ interference}

RNA interference (RNAi) was employed in this study to inhibit $J W A$ expression and further analyze $J W A$ gene function. The PCR-based siRNA expression cassettes (SECs) were built using a Silencer ${ }^{\mathrm{TM}}$ Expression Kit (Ambion Inc, Austin, TX) to express siRNA of $J W A$ in cells and in turn to suppress $J W A$ expression according to the manufacturer's manual. Target site of $J W A$ siRNA was determined by the on-line tool from Ambion Company and the sequence located downstream of the start codon was selected: AA ATGGAACAACCGCGTAGTG. The Silencer ${ }^{\text {TM }}$ Expression Kit also supplied the negative control, which expresses a hairpin siRNA with limited homology to the human, mouse, and rat genome sequences. Transfecting the negative control siRNA into cells has no known specific effects on gene expression. In this study, we used the negative control SECs as an effective transfection control for experiments with SECs of $J W A$. SECs were delivered into the cells using siPORT XP-1 (Ambion), a polyamine-based DNA transfection agent, following the detailed instructions provided with the product.

\section{Cell differentiation analysis}

Cell differentiation was determined by the expression of myelomonocytic antigen CD11b by flow cytometry. Cells were collected, washed with PBS twice and then incubated with CD11b-PE (Immunotech, Prague) or the negative control IgG-PE (Immunotech, Prague) solution respectively in the dark for $30 \mathrm{~min}$. The cells were washed twice in PBS and detected by FACSCalibur flow cytometer (Becton Dickinson Inc.). Myelomonocytic differentiation was also measured by nitroblue tetrazolium (NBT) reduction assay and morphology using light microscopy of cytospin preparations stained by Wight-Giemsa methods [3]. Data were expressed as means \pm SD of three separate experiments performed in duplicate.

\section{Cell viability, cell growth and cell cycle analysis}

Cell viability was assayed by exclusion of $0.2 \%$ trypan blue and then the cell numbers were counted under the light microscopy. The cell-cycle profiles were measured by flow cytometry. Briefly, cells were collected and washed, then stained with propidium iodide solution (PI, Becton dicinson Inc.) at $4{ }^{\circ} \mathrm{C}$ for $30 \mathrm{~min}$. The samples were detected by FACSCalibur flow cytometer (Becton Dickinson Inc.). Data were expressed as means \pm SD of three separate experiments performed in duplicate.

\section{Western blot analysis}

Western blotting was carried out according to the standard protocol. Harvested cells were washed with PBS twice and added in 100-200 $\mu$ l of keratin extraction buffer ( $1 \%$ triton-X 100, $0.02 \mathrm{mM}$ Tris, $\mathrm{pH} 7.0,0.6 \mathrm{M} \mathrm{KCl}$ and $1 \mathrm{mM}$ PMSF). The samples were centrifuged at $12,000 \times g$ for $5 \mathrm{~min}$ and discarded to remove pellets. The protein concentrations of the samples were measured. The 
samples containing equal amount of protein were separated by $12.5 \%$ SDS-PAGE gel and then transferred onto a nitrocellulose membrane by electroblotting. The membranes were incubated with anti-JWA polypeptide serum (rabbit polyclonal serum, dilution at 1:200) and anti- $\beta$-actin antibody (rabbit polyclonal antibody, dilution at 1:300, Bost Bio-engineering Inc., Wuhan, China). JWA c-terminal 20 amino acid peptide and the antiJWA polypeptide sera were prepared by Research Genetics Inc (USA). The membranes were washed by PBST $(5 \times 5 \mathrm{~min})$ before being incubated with horseradish peroxidase (HRP)-labeled second antibody (1:300 dilution). Immunoreactive bands were detected using DAB substrate (Bost Bio-engineering Inc., Wuhan, China) and analyzed by Bandscan software. JWA protein expression was normalized by the quantity of $\beta$-actin. The bands were the representative of three independent experiments. The gray values were expressed in relation to that of control and presented as means $\pm \mathrm{SD}$ of the three independent experiments.

\section{RNA Isolation and RT-PCR analysis}

Total cellular RNA was extracted from the cells and reverse-transcription (RT) reactions were performed as described previously $[16,17]$. PCR amplification was carried out in PE 480 Thermal Cycler (Perkin Elmer Inc.) as follows: $95{ }^{\circ} \mathrm{C}$ for $5 \mathrm{~min}$, then 30 cycles consisting of $30 \mathrm{~s}$ at $95^{\circ} \mathrm{C}$, $45 \mathrm{~s}$ at the annealing temperature $58^{\circ} \mathrm{C}$ and $30 \mathrm{~s}$ at $72{ }^{\circ} \mathrm{C}$ for extending. After the last cycle, incubation at $72^{\circ} \mathrm{C}$ was prolonged for $10 \mathrm{~min}$. $\beta$-actin was used for normalizing $J W A$ expression and amplified simultaneously. The primers of $J W A$ (281 bp) and $\beta$-actin (270 bp) were as follows: $J W A$-forward, 5'-CACCCAGCAAGTA TTTGTTGCAAAC-3' $J W A$-reverse, 5'-CCTTA GGGGCACAAGGAGGAC-3'; $\beta$-actin-forward, $5^{\prime}$-CTACAATGAGCTGCGTGTGGC-3', $\beta$-actin-reverse, 5'-CAGGTCCAGACGCAGGATGG $\mathrm{C}-3^{\prime}$. PCR products $(10 \mu \mathrm{l})$ were analyzed on $2 \%$ agarose gel in TBE buffer. Band intensity was quantified by Bandscan software. The gray values of $J W A$ bands were normalized by those of $\beta$ actin. The bands were the representative of three independent experiments. The gray values were expressed in relation to that of control and presented as means $\pm \mathrm{SD}$ of the three independent experiments.

\section{Reporter plasmids}

Wild type $-1680 /+107\left(-1680 \mathrm{PCAT}^{\mathrm{wt}}\right),-595 /+107$ $\left(-595 \mathrm{PCAT}^{\mathrm{wt}}\right),-494 /+107\left(-494 \mathrm{PCAT}^{\mathrm{wt}}\right),-257 /$ $+107 \quad\left(-257 \mathrm{PCAT}^{\mathrm{wt}}\right),-194 /+107 \quad\left(-194 \mathrm{PCAT}^{\mathrm{wt}}\right)$ and $-107 /+107\left(-107 \mathrm{PCAT}^{\mathrm{wt}}\right)$ bp fragments of the human $J W A$ promoter were cloned at ScaI ( $\left.3^{\prime}\right)$ and $\mathrm{XhoI}\left(5^{\prime}\right)$ restriction sites into the pCAT3-basic vector (Promega, Madison, WI). All constructs were confirmed prior to use by restriction enzyme digestions and DNA sequencing.

\section{CAT reporter gene assay}

For transfection experiments, HL-60 cells were seeded onto six-well plates $\left(2 \times 10^{5}\right.$ cells/well). Each well was transfected with $3.2 \mu \mathrm{g}$ of reporter vector DNA, using PolyFect transfection reagent (Qiagen, Valencia, CA). For co-transfections, $0.8 \mu \mathrm{g}$ empty $\beta$-galactosidase vector was added to each reaction. After transfection, HL-60 cells were treated with ATRA $(1 \mu \mathrm{M})$ in RPMI 1640 plus $10 \%$ FCS for $48 \mathrm{~h}$. Cell extracts were then prepared, and each sample was assayed in triplicate using a CAT-ELISA system (Roche Diagnostics $\mathrm{GmbH}$, Mannheim, Germany) according to the manufacturer's instructions. The absorbance was measured using a spectrophotometric microtiter plate reader at $405 \mathrm{~nm}$ wavelength. CAT activity was normalized with $\beta$-gal activity for transfection efficiency. Differences in reporter activities between the experimental groups were analyzed by Student's $t$ test. All statements of significance are $p<0.05$.

\section{Preparation of nuclear extracts}

Nuclear extracts from HL-60 cells were prepared as following: cells $\left(1 \times 10^{8} / \mathrm{ml}\right)$ were collected in ice-cold phosphate-buffered saline (PBS), centrifuged for $5 \mathrm{~min}$ at $1500 \times \mathrm{g}$, and washed with PBS before being recentrifuged. The pellets were resuspended in buffer (10 mM HEPES, pH 7.8, $10 \mathrm{mM} \mathrm{KCl}, 0.1 \mathrm{mM}$ EDTA, $0.1 \%$ Nonidet $\mathrm{P}-40$ ), incubated on ice for $10 \mathrm{~min}$, and homogenized. Nuclei were pelleted by centrifugation at $3000 \times g$ for $10 \mathrm{~min}$ at $4{ }^{\circ} \mathrm{C}$, followed by resuspension in buffer (50 mM HEPES, pH 7.8, $420 \mathrm{mM} \mathrm{KCl}, 5 \mathrm{mM} \mathrm{MgCl}_{2}, 0.1 \mathrm{mM}$ EDTA, $20 \%$ glycerol) and mixed by rotation at $4{ }^{\circ} \mathrm{C}$ for $1 \mathrm{~h}$. After centrifugation at $20,000 \times \mathrm{g}$ for $30 \mathrm{~min}$ at $4{ }^{\circ} \mathrm{C}$, the supernatants were collected and stored at 


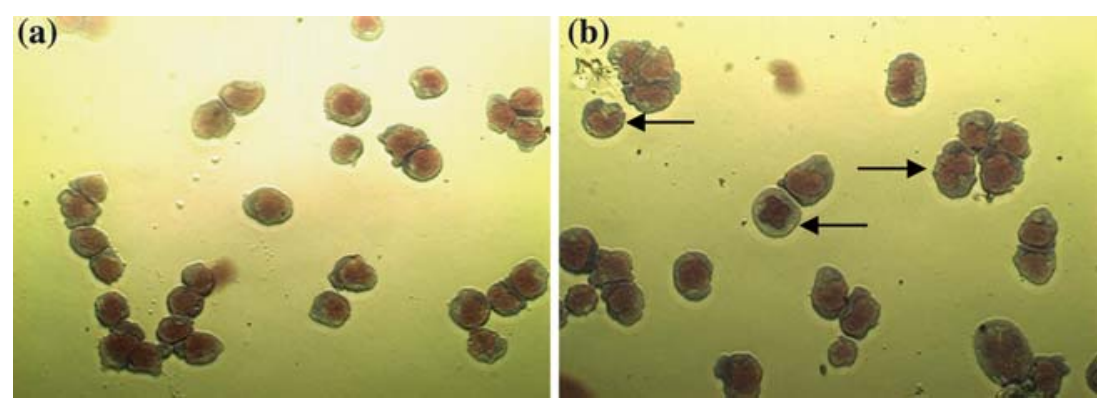

Figure 1. Representative morphological changes of HL-60 cells differentiated by ATRA treatment. Typical microscopic image of undifferentiated HL-60 cells (a) and differentiated HL-60 cells with segmented nuclei (b) stained by the Wright-Giemsa method (Magnification $\times 400$ ). HL-60 cells (b) were induced by $1 \mu \mathrm{M}$ ATRA for $72 \mathrm{~h}$.

$-80^{\circ} \mathrm{C}$ until used. The protein concentration of the nuclear extracts was determined by Bradford assay (Bio-Rad) using bovine serum albumin as a standard.

\section{Southwestern assay}

Nuclear extracts $(75 \mu \mathrm{g})$ from HL-60 cells were electrophoresed in a $12.5 \%$ SDS-polyacrylamide gel. Fractionated proteins in the gel were then electro-transferred to a PVDF-Plus filter (Micron Separations). After transferring, the filter was prehybridized with a $100 \mathrm{ml}$ hybridization buffer containing $10 \mathrm{mM}$ Tris- $\mathrm{HCl}$, $\mathrm{pH} 7.5,1 \mathrm{mM} \mathrm{MgCl}$, $0.5 \mathrm{mM}$ EDTA, $0.5 \mathrm{mM}$ DTT, $50 \mathrm{mM} \mathrm{NaCl}$, and $5 \%$ nonfat dry milk at room temperature for $1 \mathrm{~h}$, and then rinsed twice with the hybridization buffer containing $0.25 \%$ nonfat dry milk. Subsequently, The filters were hybridized for $2 \mathrm{~h}$ at room temperature with binding buffer ( $20 \mathrm{mM}$ Hepes, $\mathrm{pH} 7.9$, $100 \mathrm{mM} \mathrm{KCl}, 5 \%$ glycerol, $1 \mathrm{mM}$ EDTA, $1 \mathrm{mM}$ dithiothreitol, and $15 \mu \mathrm{g} / \mathrm{ml}$ salmon sperm DNA) containing $40 \mathrm{ng}$ of DIG labeled probe (-194 to +107 in $J W A$ promoter region), following which the filters were washed in the binding buffer at room temperature for $20 \mathrm{~min}$. The positions of the DIG end-labeled oligonucleotides were detected by a chemiluminescent reaction according to the manufacturer's instruction and visualized by autoradiography.

\section{Statistical analysis}

Data were expressed as Means $\pm \mathrm{SD}$. One-way analysis of variance (ANOVA) followed by the least significant difference (LSD) was used to assess significant differences between treatment groups. Differences were considered as significant when $p<0.05$.

\section{Results}

Differentiation and growth inhibition of HL-60 cells induced by ATRA

Studies were designed to clarify the observation that ATRA induces cell maturation-differentiation in HL-60 cells. Maturation-differentiation is accompanied by changes in cellular morphology, increased expression of the cell surface markers and decreased proliferation. The morphological changes to HL-60 cells were observed by WightGiemsa staining. The nucleus of differentiated HL-60 cells became constricted, indented, or segmented (Figure 1). Expression of CD11b antigen, the specific marker for myelomonocytic differentiation, was detected by flow cytometry. After $48 \mathrm{~h}$ exposure of HL-60 cells to ATRA at concentrations of $0.01,0.1,1$ and $10 \mu \mathrm{M}$, the expression of $\mathrm{CD} 11 \mathrm{~b}$ was 25.9, 36.5, 45.4 and $60.5 \%$ respectively (Figure $2 \mathrm{a}$ ). And it was 57.2 , and $70.5 \%$ with the treatment of $1 \mu \mathrm{M}$ ATRA for 4 and 6 days respectively (Figure 3a). The extent of differentiation of HL-60 cells was also determined by the method based on NBT reducing activity (Figures $2 \mathrm{~b}$ and $3 \mathrm{~b}$ ) and similar results were obtained that differentiation of HL-60 cells was induced by ATRA in a dose- and timedependent manner. Generally, the inhibition of cell proliferation paralleled this effect (Figures 2c and $3 \mathrm{c}$ ). In addition, there was minimal loss of viability after treatment for $48 \mathrm{~h}$ with ATRA at $0.01,0.1$ and $1 \mu \mathrm{M} .10 \mu \mathrm{M}$ of ATRA caused 
(a)

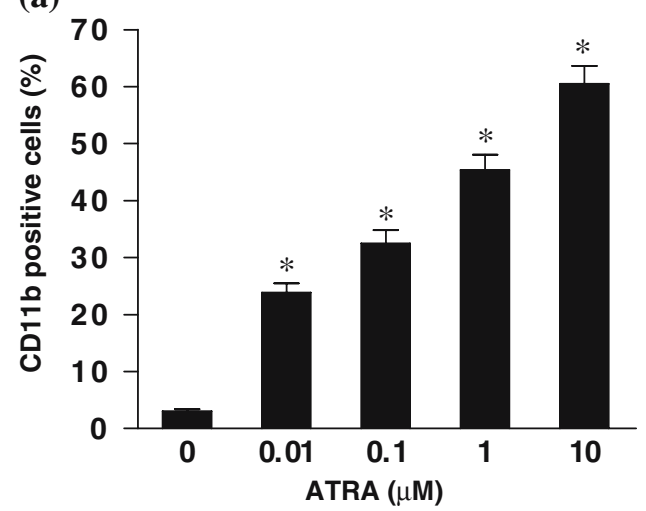

(c)

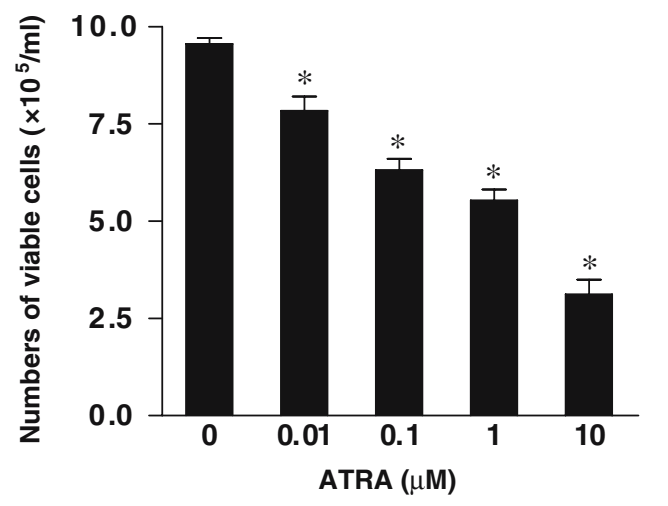

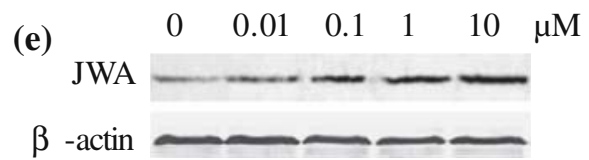

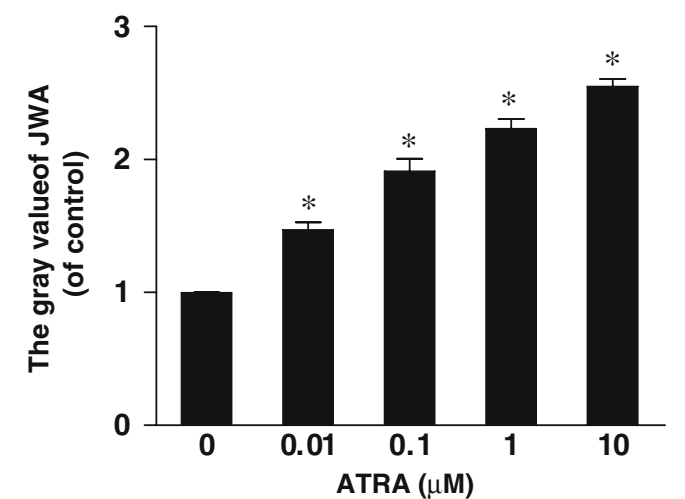

(b)

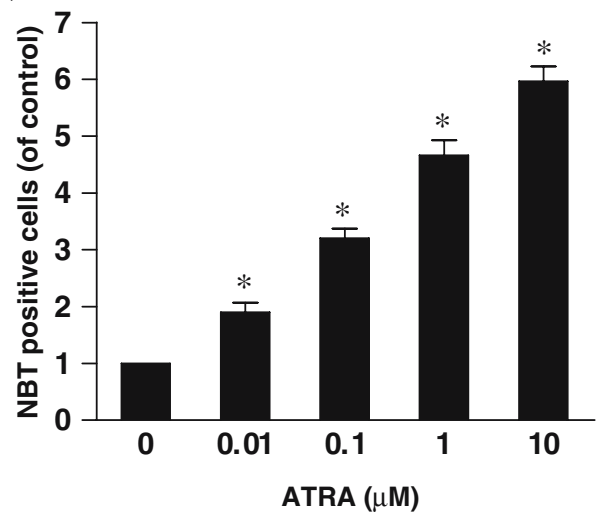

(d)

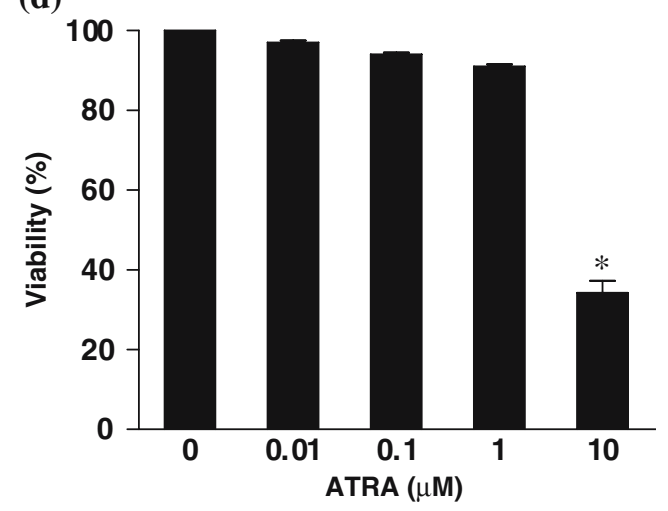

Figure 2. Dose-dependent induction by ATRA of the cell differentiation and growth inhibition and JWA expression in HL-60 cells. HL-60 cells $\left(5 \times 10^{5}\right.$ cells $\left./ \mathrm{ml}\right)$ were incubated with $0.01,0.1$ and $1 \mu \mathrm{M}$ ATRA for $48 \mathrm{~h}$ respectively. (a) CD11b expression was analyzed by flow cytometry. (b) NBT reduction activity. Results were expressed as the mean of percentage of control dishes that contained no retinoid. (c) Viable cell counts by trypan blue dye exclusion. (d) Cell viability estimated by trypan blue dye exclusion. (e) JWA protein was measured by Western blot analysis and the gray value was analyzed according to "Materials and methods". ${ }^{*} p<0.05$, compared with untreated control. 
(a)

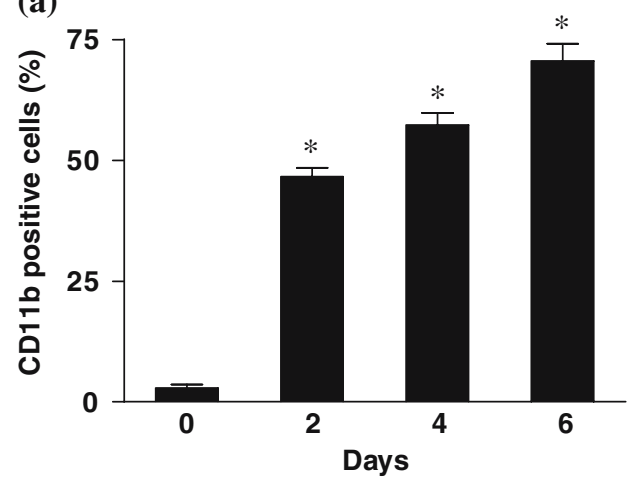

(c)

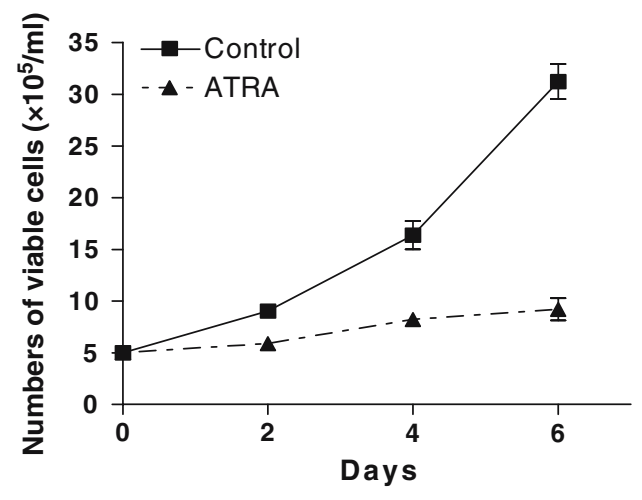

(b)

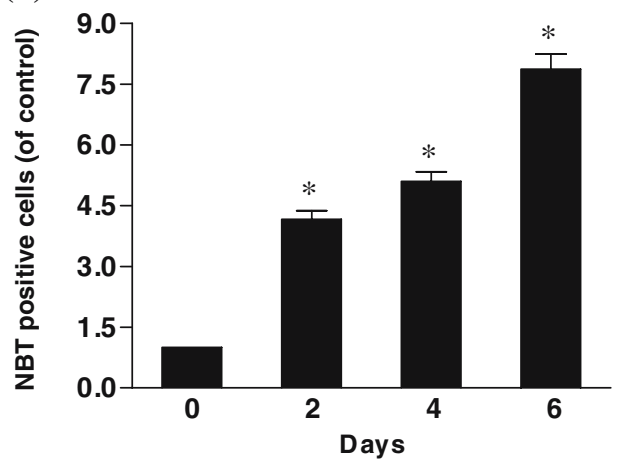

(d)
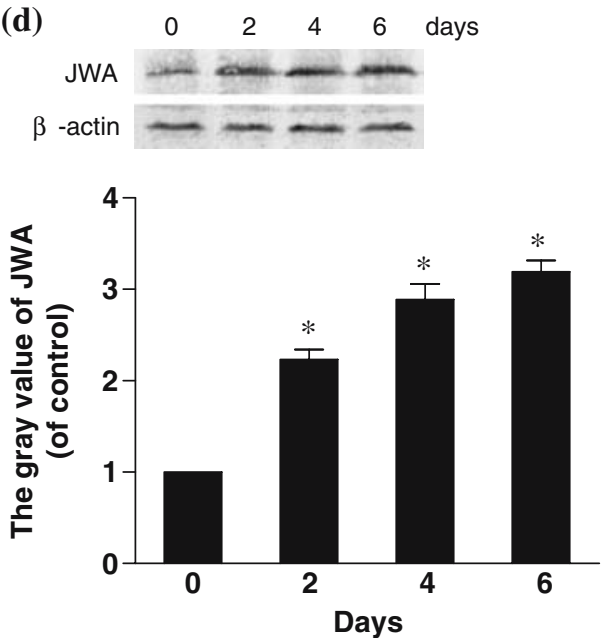

Figure 3. Time-dependent induction by ATRA of the cell differentiation and growth inhibition and JWA expression in HL-60 cells. HL- 60 cells $\left(5 \times 10^{5}\right.$ cells $\left./ \mathrm{ml}\right)$ were treated with $1 \mu \mathrm{M}$ ATRA for 2,4 and 6 days respectively. (a) CD11b expression was analyzed by flow cytometry. (b) NBT reduction activity. Results were expressed as the mean of percentage of control. (c) Viable cell counts by trypan blue dye exclusion. (d) JWA protein was measured by Western blot and the gray value was analyzed. ${ }^{*} p<0.05$, compared with untreated control.

$65 \%$ loss of viability of HL-60 cells (Figure $2 \mathrm{~d}$ ). Since the treatment with $1 \mu \mathrm{M}$ ATRA for $48 \mathrm{~h}$ was much effective and slightly toxic, in agreement with previous reports, these incubation period and concentration were used for subsequent studies.

\section{Up-regulation of JWA expression by ATRA}

In the process of differentiation and growth inhibition of HL-60 cells, JWA protein expression was up-regulated by ATRA. It was 1.47-, 1.91-, 2.23- and 2.55-fold of the control after $48 \mathrm{~h}$ exposure of HL-60 cells to ATRA at concentrations of $0.01,0.1,1$ and $10 \mu \mathrm{M}$ (Figure 2e), and it was $2.82-$ and 3.19 -fold with $1 \mu \mathrm{M}$ ATRA treatment for 96 and $144 \mathrm{~h}$ respectively (Figure 3d). These results suggested that up-regulation of JWA protein expression by ATRA was in a time- and dose-dependent manner.

\section{Inhibition of JWA expression by RNAi partially blocked ATRA-induced differentiation and growth inhibition of HL-60 cells}

We performed RNA interference to further investigate the role of $J W A$ in ATRA-induced differentiation of HL-60 cells. PCR-based SECs were built to express siRNA in HL-60 cells. As shown in Figure $4 \mathrm{a}$ and $\mathrm{b}$, no significant inhibition on both mRNA and protein expression of $J W A$ was observed in cells transfected with SECs of the negative control for $72 \mathrm{~h}$. However, in cells transfected with SECs against $J W A$ for $72 \mathrm{~h}, J W A$ mRNA was hardly detected and protein expression 


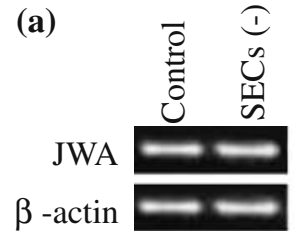

(c)

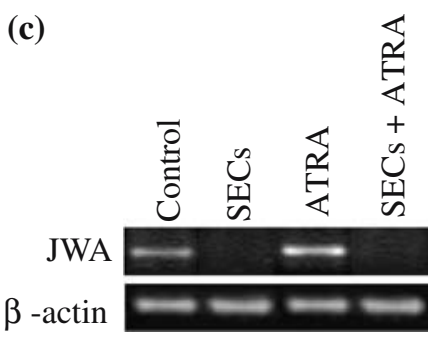

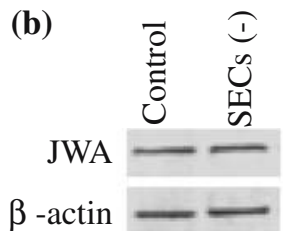

(d)

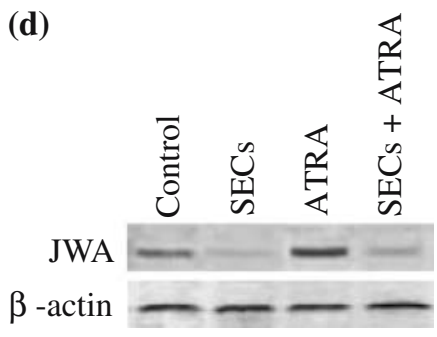

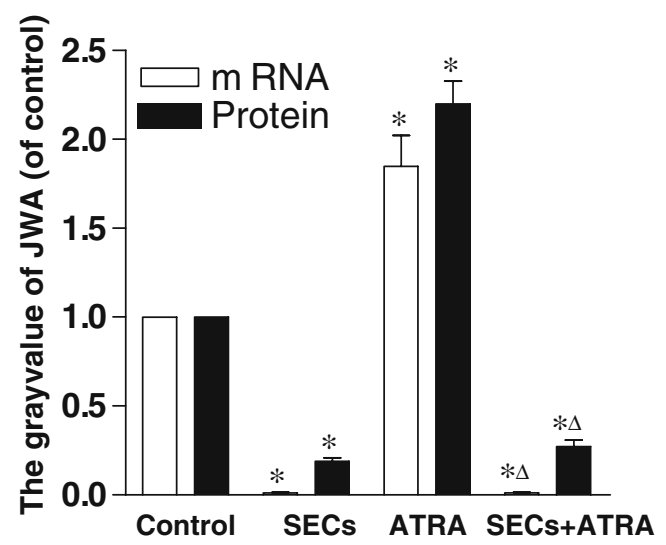

Figure 4. RNAi of JWA reduced ATRA-induced cell differentiation and growth inhibition in HL-60 Cells. HL-60 cells $\left(5 \times 10^{5}\right.$ cells $/ \mathrm{ml}$ ) (a and b) were left untreated or transfected by SECs(-) (SECs of the negative control) for $72 \mathrm{~h}$. Little effect of SECs(-) was observed on JWA mRNA expression detected by RT-PCR (a) and protein expression measured by Western blot (b). The bands were the representative of three independent experiments. HL-60 cells $\left(5 \times 10^{5} \mathrm{cells} / \mathrm{ml}\right)(\mathrm{c}-\mathrm{g})$ were left untreated, transfected by SECs $(-)$ or SECs of $J W A(72 \mathrm{~h})$ alone, treated with ATRA $(1 \mu \mathrm{M}, 48 \mathrm{~h})$ alone or treated with ATRA $(1 \mu \mathrm{M}, 48 \mathrm{~h})$ following SECs(-) or SECs of JWA pre-transfection $(24 \mathrm{~h})$. JWA mRNA (c) and protein (d) expression were both inhibited obviously by RNAi of $J W A$ specific SECs. (e) CD1lb expression was analyzed by flow cytometry. (f) NBT reduction activity. (g) Viable cell counts by trypan blue dye exclusion. ${ }^{*} p<0.05$, compared with untreated control; ${ }^{\Delta} p<0.05$, compared with the group treated by ATRA alone.

was down-regulated significantly ( $82 \%$ decrease) (Figure $4 \mathrm{c}$ and $\mathrm{d}$ ). These data demonstrated that SECs-mediated RNAi could effectively inhibit $J W A$ expression. As compared with the control, mere transfection with SECs of the negative control had no effect on HL-60 cell differentiation and proliferation, and similar results could also be obtained in cells only transfected with SECs against $J W A$ (Figure 4e, f and g). Transfection with SECs of the negative control for $24 \mathrm{~h}$ prior to ATRA $(1 \mu \mathrm{M}, 48 \mathrm{~h})$ treatment did not affect ATRA-induced differentiation and growth inhibition of HL-60 cells (Figure 4e, f and g). However, pre-transfection with SECs against $J W A$ for $24 \mathrm{~h}$, as compared with the treatment of ATRA $(1 \mu \mathrm{M}, 48 \mathrm{~h})$ alone, caused the marked decline of $\mathrm{CD} 11 \mathrm{~b}$ expression (from 45.3 to $31.1 \%$ ), indicating that the reduction of ATRA-induced HL-60 cell differentiation was associated with $J W A$ inhibition (Figure 4e), which was also supported by the results from NBT reduction assays (Figure 4f). At the same time, the increased numbers of HL-60 cells (Figure 4g) showed that the antiproliferation effect of ATRA was weakened by the inhibition of $J W A$ expression. 
(e)
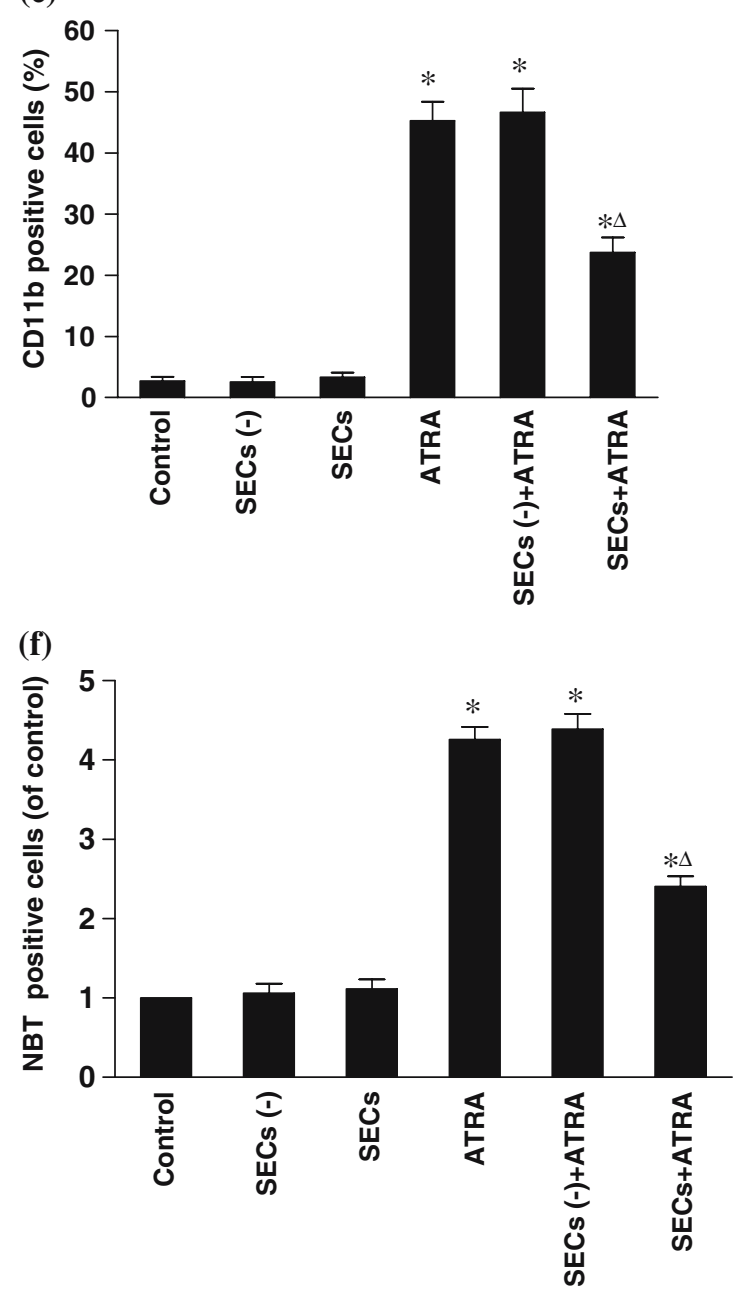

(g)

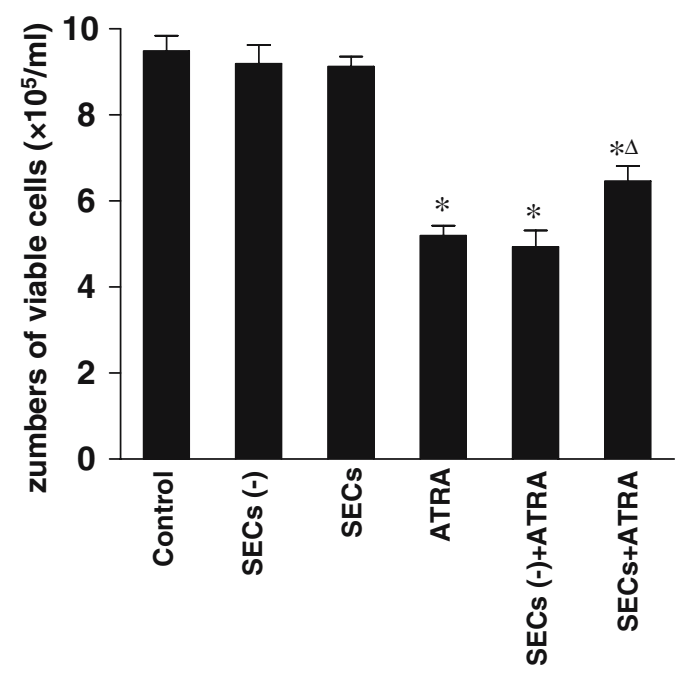

Figure 4. Continued
Effect of TPA pre-treatment on ATRA-induced $H L-60$ cell differentiation

Treatment of HL-60 cells with 0.01 or $0.1 \mathrm{nM}$ TPA had no significant effect on cell differentiation (CD11b expression was $4-5 \%$ after the treatment for $48 \mathrm{~h}$ ). A higher concentration more than $10 \mathrm{nM}$ of TPA was effective but toxic (CD11b expression was $52 \%$, but cell viability was at $40 \%$ after the treatment with $10 \mathrm{nM}$ TPA for $48 \mathrm{~h}$ ). In the present study, to investigate the effect of TPA on ATRA-induced cell differentiation, considering the efficacy and toxicity, $10 \mathrm{nM}$ of TPA was used sequentially with ATRA. We preincubated HL-60 cells that were induced for differentiation by $48 \mathrm{~h}$ treatment with $1 \mu \mathrm{M}$ ATRA, for $1 \mathrm{~h}$ with $10 \mathrm{nM}$ TPA (Figure 5). One-hour treatment with TPA resulted in the increase of $\mathrm{CD} 11 \mathrm{~b}$ expression and NBT reduction ability, indicating that cell differentiation was induced (Figure 5a and b). Simultaneously, JWA expression was down-regulated (Figure 5c). Pretreatment of ATRA-treated cells with TPA, compared with the continuous treatment with ATRA alone, resulted in the decrease of CD11b expression (from 42.2 to $20.8 \%$ ) (Figure 5a), suggesting that pre-treatment with TPA could inhibit ATRA-induced differentiation of HL-60 cells, which was supported by the results from NBT reduction assays (Figure 5b). Meanwhile, JWA expression was also down-regulated significantly (Figure 5c). There was no significant effect of TPA on cell-growth arrest induced by ATRA (data not shown).

\section{Effect of $\mathrm{As}_{2} \mathrm{O}_{3}$ on ATRA-induced differentiation and growth inhibition of HL-60 cells}

We further explored the effect of combination between $\mathrm{As}_{2} \mathrm{O}_{3}$ and ATRA. If synergism exists, considering the fact that the toxicities of ATRA and $\mathrm{As}_{2} \mathrm{O}_{3}$ are both dose-dependent [2], we postulate that the ideal therapeutic efficacy with low and tolerable toxicity may be obtained if a low dose of ATRA and a low dose of $\mathrm{As}_{2} \mathrm{O}_{3}$ are combined. In this study, HL-60 cells were co-treated with ATRA at 0.01 or $0.1 \mu \mathrm{M}$ (lower than normal pharmacological concentration) and $\mathrm{As}_{2} \mathrm{O}_{3}$ at $0.5 \mu \mathrm{M}$ (a concentration for partial differentiation with minimal apoptosis). Treat- 
(a)
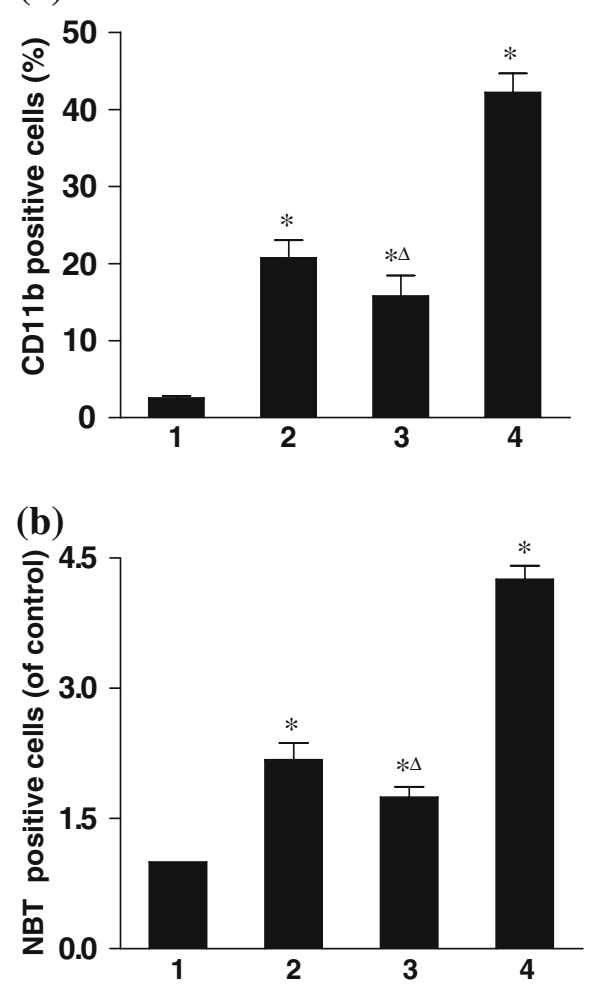

(c) JWA $\beta$-actin

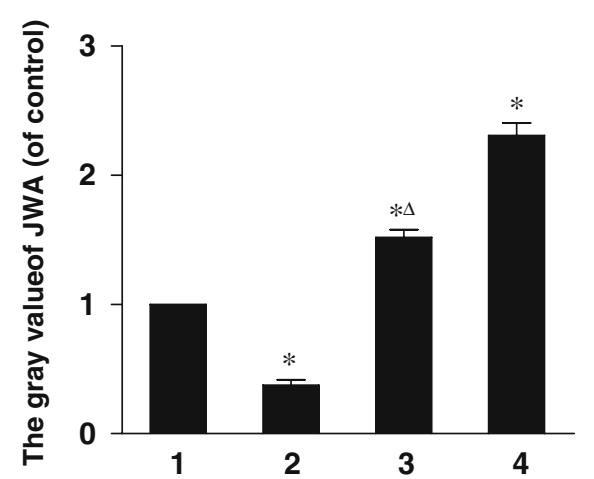

Figure 5. Pre-treatment of TPA reduced ATRA-induced cellular differentiation and $J W A$ expression in HL-60 cells. HL60 cells $\left(5 \times 10^{5}\right.$ cells $\left./ \mathrm{ml}\right)$ were left untreated (Lane 1$)$, treated with $10 \mathrm{nM}$ TPA for $1 \mathrm{~h}$, washed and incubated for $48 \mathrm{~h}$ in TPA-free medium (Lane 2), $10 \mathrm{nM}$ TPA for $1 \mathrm{~h}$, washed and incubated with $1 \mu \mathrm{M}$ ATRA for $48 \mathrm{~h}$ (Lane 3), $1 \mu \mathrm{M}$ ATRA for $48 \mathrm{~h}$ (Lane 4). (a) CD11b expression was analyzed by flow cytometry. (b) NBT reduction activity. Results were expressed as the mean of percentage of control. (c) JWA protein was measured by Western blot and the gray value was analyzed. ${ }^{*} p<0.05$, compared with untreated control; ${ }^{\Delta} p<0.05$, compared with the group treated by ATRA alone. ment with ATRA $(0.01$ or $0.1 \mu \mathrm{M})$ induced significant differentiation of HL-60 cells and $\mathrm{As}_{2} \mathrm{O}_{3}(0.5 \mu \mathrm{M})$ induced HL-60 cells undergoing partial differentiation, which were conformed by cytomorphology (data not shown), expression of $\mathrm{CD} 11 \mathrm{~b}$ as well as NBT reduction (Table 1). The combination between $0.01 \mu \mathrm{M}$ ATRA and $\mathrm{As}_{2} \mathrm{O}_{3}$ $(0.5 \mu \mathrm{M})$ increased the expression of $\mathrm{CD} 11 \mathrm{~b}$ to $39 \%$. NBT reduction ability and differentiationassociated cell-growth arrest at $\mathrm{G} 0-\mathrm{G} 1$ phase were also enhanced by the combination. However, when $0.1 \mu \mathrm{M}$ ATRA was combined with $\mathrm{As}_{2} \mathrm{O}_{3}$, no significant effect was observed (Table 1). These data indicated that $\mathrm{As}_{2} \mathrm{O}_{3}$ $(0.5 \mu \mathrm{M})$ could enhance the differentiation induced by lower concentration of ATRA $(0.01 \mu \mathrm{M})$ in HL-60 cells, but had no marked effect on the differentiation induced by higher concentration of ATRA $(0.1 \mu \mathrm{M})$. Associated with the enhancement, JWA expression was upregulated; with the unobvious effect, JWA expression was unaffected (Figure 6).

\section{ATRA potently transactivates JWA gene promoter}

As shown in Figure 4c and d, ATRA up-regulated $J W A$ on the levels of both mRNA and protein. To determine transactivating effects of ATRA on $J W A$ gene, functional transfection studies using JWA CAT reporter gene constructs $\left(-1680 \mathrm{PCAT}^{\mathrm{wt}}\right)$ were performed. ATRA $(1 \mu \mathrm{M}, 48 \mathrm{~h})$ treatment of HL-60 cells potently stimulated the JWA promoter (Figure 7). In order to identify promoter regions mediating the responsiveness of the human $J W A$ gene to ATRA treatment, series of $5^{\prime}$ deletion of the promoter were constructed and conducted the analysis. The data revealed that ATRA had a substantial influence on JWA promoter activity. The region spanning from -194 to +107 showed the best response to ATRA $(p<0.01)$. Treatment of HL-60 cells with ATRA leads to a markedly increase in cellular levels of $J W A$ expression by stimulating the transcriptional activity of $J W A$ gene promoter. To further characterize the nuclear factors binding to $J W A(-194$ to +107$)$ promoter region, southwestern blot assay was carried out. The results revealed that a band with a molecular weight of approximately $30 \mathrm{kDa}$ in the control HL60 cells disappeared after the stimulation of ATRA (Figure 8). 
Table 1. Effects of $\mathrm{As}_{2} \mathrm{O}_{3}$ on ATRA-induced differentiation and growth inhibition of HL-60 cells.

\begin{tabular}{lcllll}
\hline Treatment $(48 \mathrm{~h})$ & $\mathrm{CD}^{2} \mathrm{~b}^{\mathrm{a}}$ & $\mathrm{NBT}^{\mathrm{b}}$ & & \multicolumn{2}{l}{ Cell cycles distribution $(\%)$} \\
\cline { 5 - 6 } & & & $\mathrm{G} 1$ & $\mathrm{~S}$ & $\mathrm{G} 2+\mathrm{M}$ \\
\hline $\mathrm{Control}$ & $2.8 \pm 0.9$ & 1 & $21.9 \pm 2.3$ & $68.0 \pm 9.1$ & $10.1 \pm 2.0$ \\
$\mathrm{As}_{2} \mathrm{O}_{3}(0.5 \mu \mathrm{M})$ & $10.1 \pm 1.8^{*}$ & $1.4 \pm 0.1^{*}$ & $25.8 \pm 5.6$ & $62.7 \pm 4.9$ & $12.5 \pm 2.4$ \\
$\mathrm{ATRA}(0.01 \mu \mathrm{M})$ & $23.8 \pm 5.3^{*}$ & $1.9 \pm 0.2^{*}$ & $35.9 \pm 4.9^{*}$ & $58.0 \pm 6.2$ & $6.2 \pm 2.1^{*}$ \\
$\mathrm{As}_{2} \mathrm{O}_{3}+\mathrm{ATRA}(0.01 \mu \mathrm{M})$ & $39.2 \pm 8.2^{*} \Delta$ & $3.4 \pm 0.5^{*}$ & $46.6 \pm 5.9^{*}$ & $40.2 \pm 5.4^{*} \Delta$ & $13.2 \pm 2.6$ \\
$\mathrm{ATRA}(0.1 \mu \mathrm{M})$ & $33.0 \pm 5.6^{*}$ & $3.2 \pm 0.2^{*}$ & $41.5 \pm 5.6^{*}$ & $53.1 \pm 5.9^{*}$ & $5.4 \pm 1.4^{*}$ \\
$\mathrm{As}_{2} \mathrm{O}_{3}+\mathrm{ATRA}(0.1 \mu \mathrm{M})$ & $32.5 \pm 7.9^{*}$ & $3.0 \pm 0.3^{*}$ & $47.5 \pm 5.8^{*}$ & $38.1 \pm 4.1^{*}$ & $13.4 \pm 2.9$ \\
\hline
\end{tabular}

${ }^{\mathrm{a}} \mathrm{CD} 11 \mathrm{~b}$ positive cells; ${ }^{\mathrm{b}} \mathrm{NBT}$ positive cells (of control).

HL-60 cells were treated by 0.01 or $0.1 \mu \mathrm{M}$ ATRA with or without the combination of $\mathrm{As}_{2} \mathrm{O}_{3}(0.5 \mu \mathrm{M})$ for $48 \mathrm{~h}$. Each value was the means $\pm \mathrm{SD}$ of triplicate determinations. ${ }^{*} p<0.05$, compared with untreated control; ${ }^{\triangle} p<0.05$, compared with the related group treated by ATRA alone.

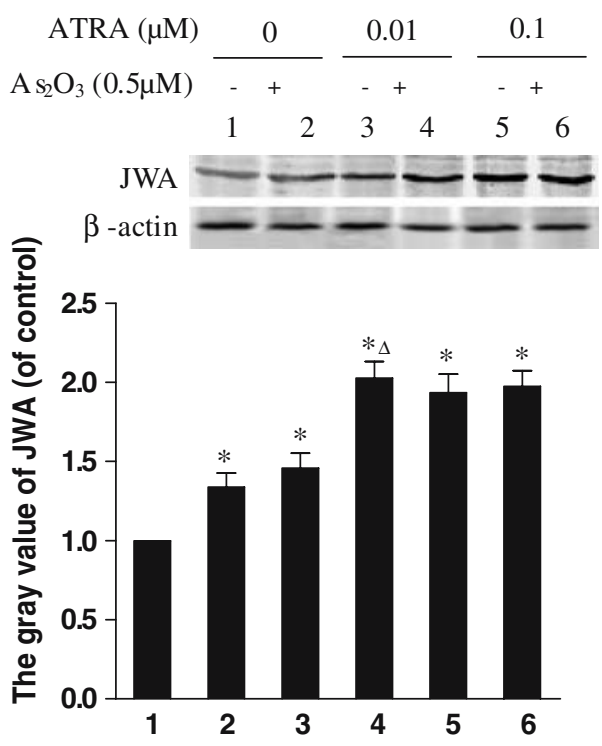

Figure 6. Effect of $\mathrm{As}_{2} \mathrm{O}_{3}$ on ATRA-induced cell differentiation and growth inhibition in HL-60 cells. HL-60 cells $\left(5 \times 10^{5}\right.$ cells $\left./ \mathrm{ml}\right)$ were treated by 0.01 or $0.1 \mu \mathrm{M}$ ATRA with or without the combination of $\mathrm{As}_{2} \mathrm{O}_{3}(0.5 \mu \mathrm{M})$ for $48 \mathrm{~h}$. Lane 1, untreated control; Lane 2, $0.5 \mu \mathrm{M} \mathrm{As}_{2} \mathrm{O}_{3}$; Lane 3, $0.01 \mu \mathrm{M}$ ATRA alone; Lane 4, $0.5 \mu \mathrm{M} \mathrm{As} \mathrm{O}_{3}+0.01 \mu \mathrm{M}$ ATRA; Lane 5, $0.1 \mu \mathrm{M}$ ATRA alone; Lane 6, $0.5 \mu \mathrm{M}$ $\mathrm{As}_{2} \mathrm{O}_{3}+0.1 \mu \mathrm{M}$ ATRA. JWA protein was measured by Western blot and the gray value was analyzed. ${ }^{*} p<0.05$, compared with untreated control; ${ }^{\Delta} p<0.05$, compared with the related group treated by ATRA alone.

\section{Discussion}

In the present study, we carried out the experiments using human myeloid leukemia HL-60 cells to explore the role of $J W A$ in ATRA-induced cell differentiation. Concurrent with the progressive cellular differentiation and growth inhibition, we found that JWA was up-regulated by ATRA in a dose- and time-dependent manner, suggesting that $J W A$, initially isolated as a novel ATRA responsible gene, might be involved in ATRA-induced cell differentiation and growth inhibition.

This was supported by the evidence that inhibition of $J W A$ expression could partially block ATRA-induced cellular differentiation and growth inhibition. Nowadays, RNAi has been promptly developed as a powerful tool to study gene function [33, 34]. In this study, we applied the PCR-based siRNA strategy [35-37] to obtain $J W A$-specific SECs and to deplete $J W A$ expression by transferring the SECs into target cells. The PCR products, referred to as SECs, comprise an RNA polymerase promoter upstream of a hairpin siRNA template, with a downstream RNA polymerase terminator, and flanking restriction enzyme sites. When transfected into mammalian cells, SECs are transcribed by endogenous RNA polymerase to generate hairpin siRNAs and knock down the expression of target gene. The results here showed that $J W A$ mRNA expression was hardly detected and protein expression was also inhibited significantly in HL-60 cells transfected with $J W A$ SECs, demonstrating that SECs-mediated RNAi against $J W A$ knocked down $J W A$ expression effectively. As a consequence, knockdown of $J W A$ expression inhibited the cellular differentiation induced by ATRA, thus implying an important role of $J W A$ as a mediator in this process. The actions of ATRA are mediated by binding to nuclear receptors (RARs), which 


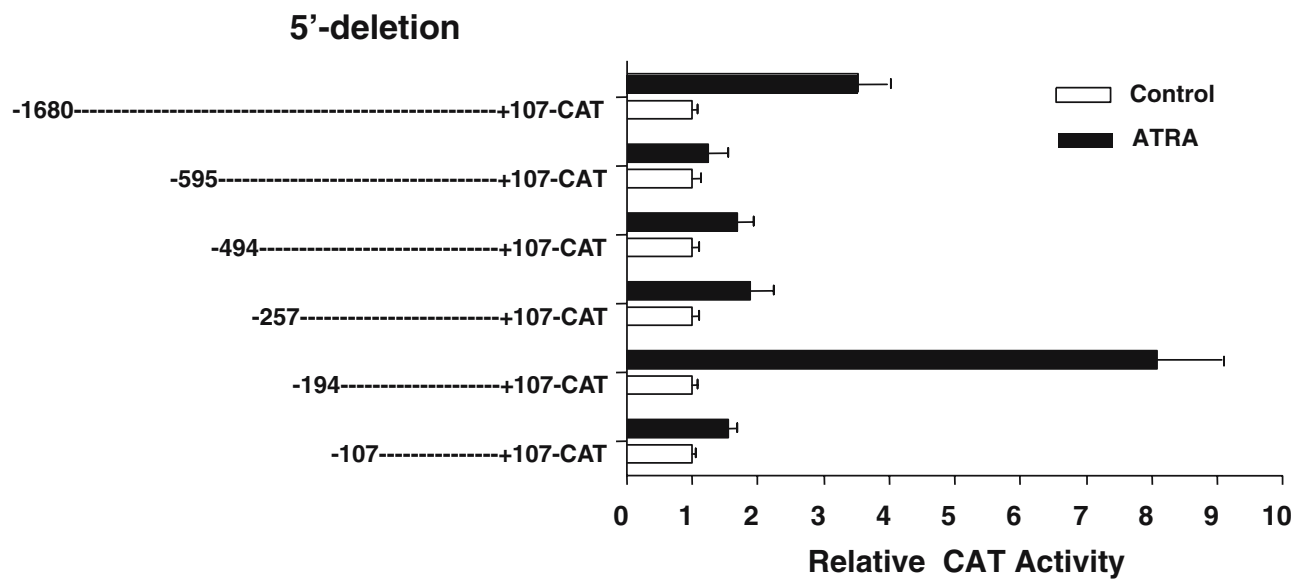

Figure 7. ATRA increases the transcriptional activity of $J W A$ in HL-60 cells. Transient transfection assays were performed with CAT reporter plasmids containing series of $J W A$ promoter fragments. CAT activity was determined in cells incubated with ATRA $(1 \mu \mathrm{M})$ for $48 \mathrm{~h}$ as described in the Materials and methods. The lines and numbers indicate the sequence (in bp) contained in each promoter-reporter constructs. The chat on the right side indicates the relative CAT activity level for each promoter-reporter constructs. The distal sequence from -194 to +107 containing two CCAAT box elements was able to confer responsiveness to ATRA $(p<0.01)$. All transient transfection studies were conducted in triplicate on three separate occasions. The chart reports the means of three experiments.

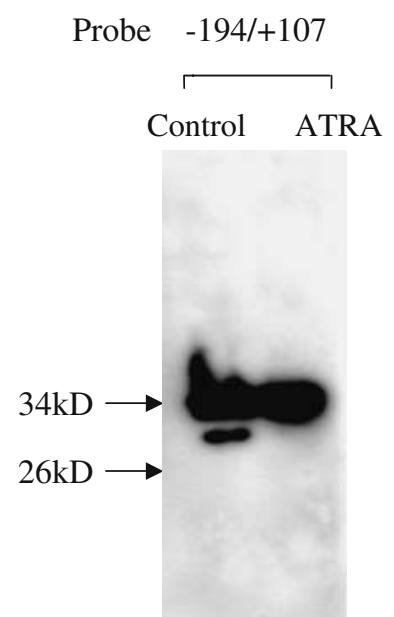

Figure 8. Southwestern analysis was performed as described in Materials and methods. Seventy five micrograms of HL-60 cell nuclear extracts were subjected to SDS-PAGE. After incubating in blocking buffer $(5 \%$ non-fat dry milk in $10 \mathrm{mM}$ HEPES, pH 7.8), the blot was hybridized with $40 \mathrm{ng}$ of DIG-labeled probe (-194 to +107 in $J W A$ promoter region). A $30 \mathrm{kDa}$ band is shown to interact with the probe in the control HL-60 cells.

normally act as ligand-inducible transcription factors by binding as heterodimers with the retinoid X receptors (RXRs) to RA response elements (RAREs) located in regulatory regions of target genes [5]. However, there is increasing evidence that nuclear receptors can mediate rapid extragenomic effects that stimulate signaling pathways by still not well-defined mechanisms, which are independent of receptor binding to DNA response elements [38]. Our results provide some interesting new insights into the underlying regulatory mechanisms for cell differentiation and growth inhibition induced by ATRA in HL-60 cells. In consideration of the fact that the block of cellular differentiation by knockdown of $J W A$ expression was incomplete, it is entirely possible that ATRA-induced differentiation is mediated by multiple mechanisms, of which $J W A$ is the only one signal molecular.

TPA provokes differentiation of HL-60 cells to monocyte/macrophage-like cells. Differentiation induced by both TPA and ATRA was shown to associate with alteration in PKC activity [25-30]. We have, therefore, tested the effect of their combinations in HL-60 cells. Our data here demonstrated that treatment with TPA and ATRA alone induced the differentiation of HL-60 cells. However, pre-treatment with TPA decreased ATRA-induced differentiation, indicating that TPA could not exert a positive cooperativity with ATRA. Simultaneously, the expression of JWA induced by ATRA was also weakened. These results further suggested that up-regulation of JWA expression was essential for ATRA-induced 
cellular differentiation. But what is the mechanism involved in the antagonism between ATRA and TPA? As shown in Figure 5c, JWA expression was decreased with the treatment of TPA. Thus, TPA might inhibit ATRA-induced cellular differentiation via down-regulating the expression of JWA. On the other hand, it was reported that the differentiation of HL-60 cells induced by ATRA was accompanied by a decrease in PKC activity [39]. Radominska-Pandya et al. [40] provided the first evidence for the direct binding of ATRA to PKC isozymes that could decrease the activation of PKC $\alpha$. TPA can substitute for diacylglycerol which is transiently produced in vivo from phospholipids such as phosphatidylinositol, and stimulates PKC when intracellular levels of calcium are low [30]. PKC itself is believed to be a receptor for TPA [30]. Thus TPA, as a PKC activator, might also decrease ATRA-induced differentiation via activating PKC directly. Taken together, directly activated PKC by TPA was associated with the down-regulation of JWA expression, up-regulated JWA expression by ATRA was accompanied by a decrease in PKC activity. Then, what is the exact relationship between $J W A$ and PKC in the signal pathways? We presume that there might be a negative feedback between JWA and PKC. More details of these two molecular interactions need further investigation.

We also investigated the effect of $\mathrm{As}_{2} \mathrm{O}_{3}$ on ATRA-induced cell differentiation. It has been reported that ATRA induces differentiation of APL blasts, APL cell line NB4 and human myeloid leukemia cell line HL-60 (initially isolated from an APL patient). However, HL-60 cells and primary cultured APL cells are less sensitive than NB4 cells toward $\mathrm{As}_{2} \mathrm{O}_{3}(\geqq 1 \mu \mathrm{M})$ induced apoptosis [41]. And they can undergo partial differentiation by the induction of 0.1 to $1 \mu \mathrm{M} \mathrm{As}_{2} \mathrm{O}_{3}$, while NB4 cells cannot [42, 43]. To explore the combined effect between ATRA and $\mathrm{As}_{2} \mathrm{O}_{3}$, we used HL-60 cells as an induction model in vitro because of the similarity of them with APL cells. We found that $\mathrm{As}_{2} \mathrm{O}_{3}$ had different effects on the efficacy of ATRA at different concentrations. $\mathrm{As}_{2} \mathrm{O}_{3}(0.5 \mu \mathrm{M})$ only potentiated cell differentiation and growth inhibition induced by $0.01 \mu \mathrm{M}$ ATRA but had no significant effect on cell differentiation and growth inhibition by $0.1 \mu \mathrm{M}$ ATRA. Moreover, results obtained by $0.01 \mu \mathrm{M}$ ATRA plus $\mathrm{As}_{2} \mathrm{O}_{3}$
$(0.5 \mu \mathrm{M})$ were as pronounced as those obtained by $0.1 \mu \mathrm{M}$ ATRA alone. Because ATRA and $\mathrm{As}_{2} \mathrm{O}_{3}$ are already used successfully in the treatment of APL, these results herein that reducing the concentrations of ATRA and $\mathrm{As}_{2} \mathrm{O}_{3}$ allowed therapeutic efficacy with tolerable toxicity may have important clinical applications. Then what might be the basis for this enhancement effect of $\mathrm{As}_{2} \mathrm{O}_{3}$ ? Andre et al. [44] reported that such potentiating effect in APL may be explained by $\mathrm{As}_{2} \mathrm{O}_{3}$-induced PML/RAR $\alpha$ degradation. But in HL-60 cells without $\mathrm{t}(15 ; 17)$ rearrangement, there is not the expression of PML/RAR $\alpha$ fusion protein, indicating that the explanation lies elsewhere. In this study, the expression of JWA agreed well with the levels of HL-60 cell differentiation. $\mathrm{As}_{2} \mathrm{O}_{3}$ may enhance the differentiation induced by $0.01 \mu \mathrm{M}$ ATRA via increasing the expression of JWA. Up-regulation of $J W A$ expression may contribute to the induction of differentiation of HL-60 cells by ATRA, and $J W A$ may be a novel molecular marker for it.

Then, how does ATRA regulate $J W A$ gene? Retinoic acid (RA) promotes granulocytic differentiation of normal hematopoietic cells and malignant myeloid progenitors by transcriptional modulation of myeloid regulatory genes [45, 46]. Our data herein revealed that ATRA had a substantial influence on $J W A$ promoter activity. The region in $J W A$ promoter spanning from -194 to +107 showed the best response to ATRA. To further characterize the nuclear factors binding to this region, southwestern blot assay was performed and revealed that a band with a molecular weight of approximately $30 \mathrm{kDa}$ in the control HL-60 cells disappeared after the stimulation of ATRA, which gave us an insight that it might be a negative inhibitor involved in the transcriptional modulation of $J W A$ gene. Analyzing the promoter region from -194 to +107 , we found that it does not contain RAREs, but two CCAAT boxes. To identify the nuclear binding proteins in this core promoter of $J W A$, we performed a computer analysis (transfac.gbf.de/TRANSFAC/). The CCAAT motif is recognized by transcription factors such as CBF/NF-Y, NF-1, C/EBP, and GATA-1. All of them are involved in ATRAmodulated gene transcription, among which $\mathrm{C} /$ EBP in particular, plays an important role in ATRA-induced myeloid differentiation [47]. To date, at least six distinct members of the C/EBP 
family of DNA-binding proteins have been identified. These include $\mathrm{C} / \mathrm{EBP} \alpha, \mathrm{C} / \mathrm{EBP} \beta, \mathrm{C} / \mathrm{EBP} \gamma$, $\mathrm{C} / \mathrm{EBP} \delta, \mathrm{C} / \mathrm{EBP} \varepsilon$, and $\mathrm{C} / \mathrm{EBP} \zeta$ (also known as $\mathrm{C} /$ EBP homologous protein (CHOP) or growth arrest and DNA-damage inducible gene 153 [GADD153]) [48]. Generally, they positively transactivate target gene promoters. But, CHOP has been shown to inhibit DNA-binding activity of $\mathrm{C} / \mathrm{EBP} \alpha$ and $\mathrm{C} /$ EBP $\varepsilon$ to their myeloid target genes and therefore inhibit the transcriptional activation mediated by $\mathrm{C} / \mathrm{EBP} \alpha$ and $\mathrm{C} / \mathrm{EBP} \varepsilon$ [47]. Although CHOP was initially determined as a negative inhibitor of $\mathrm{C} /$ EBPs, later studies showed that under certain circumstances, CHOP-C/EBP heterodimers are capable of recognizing a novel DNA target sequence and, hence, of activating gene transcription [49]. With respect to ATRA-induced transcriptional modulation of $J W A$ gene, which nuclear factor with a molecular weight of approximately $30 \mathrm{kDa}$ acts as an a negative transcriptional inhibitor and whether it is associated with the $\mathrm{C} / \mathrm{EBP}$ family are required to be further determined.

\section{Acknowledgements}

This work was supported partially by the National Natural Science Foundation of China (Nos. 30471430 and 30170812) and National Key Basic Research (973) Project (No. 2002CB512900).

\section{References}

1. Zauli G., Visani G., Bassini A., Caramelli E., Ottaviani E., Bertolaso L., Bertagnolo V., Borgatti P. and Capitani S., Nuclear translocation of protein kinase C-alpha and -zeta isoforms in HL-60 cells induced to differentiate along the granulocytic lineage by all-trans retinoic acid. Br. J. Haematol. 93: 542-550, 1996.

2. Tallman M.S., Nabhan C., Feusner J.H. and Rowe J.M., Acute promyelocytic leukemia: evolving therapeutic strategies. Blood 99: 759-767, 2002.

3. Idres N., Benoit G., Flexor M.A., Lanotte M. and Chabot G.G., Granulocytic differentiation of human NB4 promyelocytic leukemia cells induced by all-trans retinoic acid metabolites. Cancer Res. 6: 700-705, 2001.

4. Launay S., Gianni M., Diomede L., Machesky L.M., Enouf J. and Papp B., Enhancement of ATRA-induced cell differentiation by inhibition of calcium accumulation into the endoplasmic reticulum: cross-talk between RAR $\alpha$ and calcium-dependent signaling. Blood 101: 3220-3228, 2003.

5. Chambon P., A decade of molecular biology of retinoic acid receptors. FASEB J. 10: 940-954, 1996.
6. Zhou J.W., Di Y.P. and Zhao Y.H. A novel cytoskeleton associate gene-cloning, identification, sequencing, regulation of expression and tissue distribution of JWA. In: Ye X.S., Shen B.F. and Tang X.F. (Eds), Investigation on Cell Modulation: Signal Transduction, Apoptosis and Gene Expression. Beijing, 1999, pp. 110-119.

7. Lin C.I., Orlov I., Ruggiero A.M., Dykes-Hoberg M., Lee A., Jackson M. and Rothstein J.D., Modulation of the neuronal glutamate transporter EAAC1 by the interacting protein GTRAP3-18. Nature 410: 84-88, 2001.

8. Butchbach M.E., Lai L. and Lin C.L., Molecular cloning, gene structure, expression profile and functional characterization of the mouse glutamate transporter (EAAT3) interacting protein GTRAP3-18. Gene 292: 81-90, 2002.

9. Butchbach M.E., Guo H. and Lin C.L., Methyl-betacyclodextrin but not retinoic acid reduces EAAT3mediated glutamate uptake and increases GTRAP3-18 expression. J. Neurochem. 84: 891-894, 2003.

10. Schweneker M., Bachmann A.S. and Moelling K., JM4 is a four-transmembrane protein binding to the CCR5 receptor. FEBS Lett. 579: 1751-1758, 2005.

11. Ingley E., Williams J.H., Walker C.E., Tsai S., Colley S., Sayer M.S., Tilbrook P.A., Sarna M., Beaumont J.G. and Klinken S.P., A novel ADP-ribosylation like factor (ARL6), interacts with the protein-conducting channel SEC61beta subunit. FEBS Lett. 459: 69-74, 1999.

12. Matsuda A., Suzuki Y., Honda G., Muramatsu S., Matsuzaki O., Nagano Y., Doi T., Shimotohno K., Harada T., Nishida E., Hayashi H. and Sugano S., Large-scale identification and characterization of human genes that activate NF-kappaB and MAPK signaling pathways. Oncogene 22: 3307-3318, 2003.

13. Campbell S.L., Khosravi-Far R., Rossman K.L., Clark G.J. and Der C.J., Increasing complexity of Ras signaling. Oncogene 17: 1395-1413, 1998.

14. Bar-Sagi D. and Hall A., Ras and Rho GTPases: a family reunion. Cell 103: 227-238, 2000.

15. Kyriakis J.M. and Avruch J., Mammalian mitogenactivated protein kinase signal transduction pathways activated by stress and inflammation. Physiol. Rev. 81: 807-869, 2001.

16. Shen Q., Zhou J.W., Shen R.L., Lu H., Cao H.X. and Xia W., The significance of expression of JWA gene in acute non-lymphocytic leukemia. Acta Nanjing Med. Univ. 21: 406-407, 2001(in Chinese).

17. Shen Q., Zhou J.W., Shen R.L., Lu H., Cao H.X. and Xia W., To detect the expression of JWA gene by semiquantity RT-PCR in chronic myelogenous leukemia. Jiangsu Med. J. 27: 1-3, 2001(in Chinese).

18. Xia W., Zhou J.W. and Cao H.X., The relationship between structure and function of JWA in the modulation of cell differentiation. Chinese Sci. Bull. 46: 2063-2067, 2001.

19. Cao H.X., Xia W. and Zhou J.W., The role of JWA in acute promyelocytic leukemia cell differentiation and apoptosis triggered by retinoic acid, 12-tetradecanoylphorbol-13-acetate and arsenic trioxide. Chinese Sci. Bull. 47: 834-838, 2002.

20. Savickiene J., Gineitis A. and Stigbrand T., Modulation of apoptosis of proliferating and differentiating HL-60 cells by protein kinase inhibitors: suppression of PKC or PKA differently affects cell differentiation and apoptosis. Cell Death Differ 6: 698-709, 1999.

21. Paquette R.L. and Koeffler H.P., Differentiation therapy. Hematol. Oncol. Clin. N. Am. 6: 687-706, 1992. 
22. Scott R.E., The differentiation therapy of cancer: past, present, and future. Mol. Cell Differ 3: 157-173, 1995.

23. Chou T.C. and Talalay P., Quantitative analysis of dose effect relationships: the combined effects of multiple drugs or enzyme inhibitors. Adv. Enzyme Regul. 22: 27-55, 1984.

24. Berenbaum M.C., Criteria for analyzing interactions between biologically active agents. Cancer Res. 35: 269-335, 1981.

25. Fontana J.A., Reppucci A., Durham J.P. and Miranda D., Correlation between the induction of leukemic cell differentiation by various retinoids and modulation of protein kinases. Cancer Res. 46: 2468-2473, 1986.

26. Carter C.A., Parham G.P. and Chambers T., Cytoskeletal reorganization induced by retinoic acid treatment of human endometrial adenocarcinoma (RL95-2) cells is correlated with alterations in protein kinase $\mathrm{C}$-alpha. Pathobiology 66: 284-292, 1998.

27. Newton A.C., Regulation of protein kinase C. Curr. Opin. Cell Biol. 9: 161-167, 1997.

28. Yang K.D., Mizobuchi T., Kharbanda S.M., Datta R., Huberman E., Kufe D.W. and Stone R.M., All-trans retinoic acid reverses phorbol ester resistance in a human myeloid leukemia cell line. Blood 83: 490-496, 1994.

29. Bertolaso L., Gibellini D., Secchiero P., Previati M., Falgione D., Visani G., Rizzoli R., Capitani S. and Zauli G., Accumulation of catalytically active PKC-zeta into the nucleus of HL-60 cell line plays a key role in the induction of granulocytic differentiation mediated by all-trans retinoic acid. Br. J. Haematol. 100: 541-549, 1998.

30. Kikkawa U., Takai Y., Tanaka Y., Miyake R. and Nishizuka Y., Protein kinase $\mathrm{C}$ as a possible receptor protein of tumor-promoting phorbol esters. J. Biol. Chem. 258: 11442-11445, 1983.

31. Shen Z.X., Chen G.Q., Ni J.H., Li X.S., Xiong S.M., Qiu Q.Y., Zhu J., Tang W., Sun G.L., Yang K.Q., Chen Y., Zhou L., Fang Z.W., Wang Y.T., Ma J., Zhang P., Zhang T.D., Chen S.J., Chen Z. and Wang Z.Y., Use of arsenic trioxide $\left(\mathrm{As}_{2} \mathrm{O}_{3}\right)$ in the treatment of acute promyelocytic leukemia (APL): $\|$. Clinical efficacy and pharmacokinetics in relapsed patients. Blood 89: 3354-3360, 1997.

32. Soignet S.L., Maslak P., Wang Z.G., Jhanwar S., Calleja E., Dardashti L.J., Corso D., DeBlasio A., Gabrilove J., Scheinberg D.A., Pandolfi P.P. and Warrell R.P. Jr., Complete remission after treatment of acute promyelocytic leukemia with arsenic trioxide. N. Engl. J. Med. 339: 1341-1348, 1998.

33. Hannon G.J., RNA interference. Nature 418: 244-251, 2002.

34. Elbashir S.M., Harborth J., Lendeckel W., Yalcin A., Weber K. and Tuschl T., Duplexes of 21-nucleotide RNAs mediate RNA interference in cultured mammalian cells. Nature 411: 494-498, 2001

35. Castanotto D., Li H. and Rossi J.J., Functional siRNA expression from transfected PCR products. RNA 8: 1454-1460, 2002.

36. Gou D., Jin N. and Liu L., Gene silencing in mammalian cells by PCR-based short hairpin RNA. FEBS Lett. 548: 113-118, 2003.
37. Zheng L., Liu J., Batalov S., Zhou D., Orth A., Ding S. and Schultz P.G., An approach to genome wide screens of expressed small interfering RNAs in mammalian cells. Proc. Natl. Acad. Sci. USA 101: 135-140, 2004.

38. Valverde M.A. and Parker M.G., Classical and novel steroid actions: a unified but complex view. Trends Biochem. Sci. 27: 172-173, 2002

39. Liu T.X., Zhang J.W., Tao J., Zhang R.B., Zhang Q.H., Zhao C.J., Tong J.H., Lanotte M., Waxman S., Chen S.J., Mao M., Hu G.X., Zhu L. and Chen Z., Gene expression networks underlying retinoic acid-induced differentiation of acute promyelocytic leukemia cells. Blood 96: 1496-1504, 2000.

40. Radominska-Pandya A., Chen G., Czernik P.J., Little J.M., Samokyszyn V.M., Carter C.A. and Nowak G., Direct interaction of all-trans-retinoic acid with protein kinase C (PKC). J. Biol. Chem. 275: 22324-22330, 2000.

41. Jing Y., Dai J., Chalmers-Redman R.M., Tatton W.G. and Waxman S., Arsenic trioxide selectively induces acute promyelocytic leukemia cell apoptosis via a hydrogen peroxide-dependent pathway. Blood 94: 2102-2111, 1999.

42. Cai X., Shen Y.L., Zhu Q., Jia P.M., Yu Y., Zhou L., Huang Y., Zhang J.W., Xiong S.M., Chen S.J., Wang Z.Y., Chen Z. and Chen G.Q., Arsenic trioxide-induced apoptosis and differentiation are associated respectively with mitochondrial transmembrane potential collapse and retinoic acid signaling pathways in acute promyelocytic leukemia. Leukemia 14: 262-270, 2000.

43. Jing Y., Wang L., Xia L., Chen G.Q., Chen Z., Miller W.H. and Waxman S., Combined effect of all-trans retinoic acid and arsenic trioxide in acute promyelocytic leukemia cells in vitro and in vivo. Blood 97: 264-269, 2001.

44. Andre C., Guillemin M.C. and Zhu J., The PML and PML/ RARalpha domains: from autoimmunity to molecular oncology and from retinoic acid to arsenic. Exp. Cell Res. 229: 253-260, 1996.

45. Leid M.P., Kastner R. and Lyons H., Purification, cloning, and RXR identity of the HeLa cell factor with which RAR or TR heterodimerizes to bind target sequences efficiently. Cell 68: 377-395, 1992.

46. Kliewer S.A., Umesono K., Mangelsdorf D.J. and Evans R.M., Retinoid X receptor interacts with nuclear receptors in retinoic acid, thyroid hormone and vitamin D3 signalling. Nature 355: 446-449, 1992.

47. Gery S., Park D.J., Vuong P.T., Chih D.Y., Lemp N. and Koeffler H.P., Retinoic acid regulates C/EBP homologous protein expression (CHOP), which negatively regulates myeloid target genes. Blood 104: 3911-3917, 2004.

48. Tenen D.G., Hromas R., Licht J.D. and Zhang D.E., Transcription factors, normal myeloid development, and leukemia. Blood 90: 489-519, 1997.

49. Ubeda M., Wang X.Z., Zinszner H., Wu I., Habener J.F. and Ron D., Stress-induced binding of the transcriptional factor CHOP to a novel DNA control element. Mol. Cell Biol. 16: 1479-1489, 1996. 